International Journal of Advanced Trends in Computer Science and Engineering

Available Online at http://www.warse.org/IJATCSE/static/pdf/file/ijatcse152862019.pdf

https://doi.org/10.30534/ijatcse/2019/152862019

\title{
Augmented Reality (AR) on Mobile Application for Learning Bahasa Melayu among Primary Students
}

\author{
Che Ku Nuraini Che Ku Mohd ${ }^{1}$, Faaizah Shahbodin ${ }^{2}$, Muliati Sedek ${ }^{3}$, Nadhrah Abdul Hadi ${ }^{4}$, \\ Nor Farah Naquiah Mohamad Daud \\ ${ }^{1}$ Centre for Research and Innovation Management, Pervasive Computing and Educational Technology, \\ Universiti Teknikal Malaysia Melaka, 76100 Durian Tunggal Melaka, Malaysia \\ cknuraini@utem.edu.my \\ ${ }^{2}$ Centre for Academics Excellence and Scholarship, Pervasive Computing and Educational Technology, \\ Universiti Teknikal Malaysia Melaka, 76100 Durian Tunggal Melaka, Malaysia \\ faaizah@utem.edu.my \\ ${ }^{3}$ Centre for Languages and Human Development \\ Universiti Teknikal Malaysia Melaka, 76100 Durian Tunggal Melaka, Malaysia \\ muliati@utem.edu.my \\ ${ }^{4,5}$ Fakulti Teknologi Maklumat dan Komunikasi, Universiti Teknikal Malaysia Melaka, 76100 Durian \\ Tunggal Melaka, Malaysia \\ nadhrahabdhadi@gmail.com , naquiah.daud@gmail.com
}

\begin{abstract}
The aim of the study is to develop mobile learning for Bahasa Melayu based on mobile augmented reality (AR) application. The AR technology will enhance the understanding of the subject. This improves the user's sensorial experience of the real world and provides a new way of interacting between the real world and virtual worlds with computer-generated objects. Quantitative methods were mostly preferred in this study. The respondents are primary school students' age 7 to 12 years old to master Bahasa Melayu especially in these two subtopics such as collective nouns and proverbs. An Instructional Design that is ADDIE model embedded in developing the mobile learning application. Research suggests that AR technology will enable public school students to adopt the basic principles of Bahasa Melayu in an effective learning environment. The study concludes with specific suggestions and recommendations on AR learning and recommends further studies on this interesting subject.
\end{abstract}

Key words: Augmented Reality, Mobile Application, Learning Media, Interactive Media, Primary School.

\section{INTRODUCTION}

All in the information age of a technological race to keep up with new technologies make life easier and comfortable. Multimedia technology continues to expand and influence modern education in every aspect of our lives [32]. Since this educational reform, many institutions have tried to digitize education, e-learning, online learning, the light of digital afternoons or so-called, a technology that allows information to be made everywhere and anytime [22]. Interactive technology and games-based learning curriculum activities show positive impacts on the milestones of learning, enthusiasm for school learning and engagement in subjects as they learn in school [1];[9]; [25];[26]; [28];[29].
Bahasa Melayu is an ancient language that has been used long time ago. Bahasa Melayu is the national language in Malaysia. Bahasa Melayu has now reached a high position as a language modern, as a scientific language, cultural language and literary language high quality. Mastering Bahasa Melayu is beneficial for these primary school pupils to further their studies in secondary school. It is our national language. Every Malaysian citizen must be fluent in it. Priority should be given to enhancing the command of Bahasa Melayu among pupils. However, most of primary students have problem in mastering Bahasa Melayu. This problem caused by the way of teaching Bahasa Melayu teachers and how students implement the learning in education field and daily lives. Ensuring that all Malaysians can master Bahasa Melayu should be made a priority. It is important to uphold its status as the national language. This is very important to them to achieve greater success in the future. Early stage recovery will have a more effective effect on the effort to enrich Bahasa Melayu in our country. Therefore, this project will develop an AR mobile application based on the Instructional Design model in Bahasa Melayu. Mobile learning software is called mobile education. Mobile learning is internet-based learning by the use in learning material from personal mobile devices like tablets and mobile phones via mobile apps. This gives students everywhere and every day access to education.

\section{AUGMENTED REALITY (AR) APPROACH IN EDUCATION}

Augmented Reality (AR) refers to a wide range of techniques that allow users to understand the real world of products produced by computers such as text, images and videos [5]. In reality, findings of several studies indicate that AR will help to solve the 3D visualization problem [10]; [15]; [17]; [19]; [21]. The technology of the Augmented Reality (AR) will make 
scientific concepts easier to understand, because it enhances the sensorial sense of the world by incorporating computergenerated content to the user's environment [2]; [3]. It means, therefore, that increased reality can allow a person to interact in all respects with the real world. It also reported that AR development games were built to the degree that this technology could be used in a wider range of applications and education could be of particular value. However, AR still very much adopted in education and training, it could attract and encourage students to explore and monitor the materials from various points of view [20]. The increased realism will ensure the students are more interested and inspired in the study and application of knowledge to the real world [18]. In addition, [30] mentioned that AR has a great potential for growing teaching and learning conditions, and various benefits. Since AR books are common with increased reality, AR games, discovery based learning, object simulation and training skills are common. AR gaming is also often used by educators as a tool to assist students in understanding the concept of the classroom. It is very important to consider the needs of students in building and designing a game for learning as mentioned by [27]. It enables students to develop new coding frameworks and can be used to enhance student engagement and learning through $\mathrm{AR}$ in education. $\mathrm{AR}$ mobile games with AR technologies are thus able to convey ideas for digital education in order to make learning with the schoolchild easier. In the past, games were harder to play because of certain technological limitations that prevented a large game [31].

\section{PROBLEM STATEMENTS}

Level of mastery in Bahasa Melayu among students is weak because of contamination in the field of syntax or construction of sentences. The language that they speak in their daily lives is also one of the reasons that students do not match the correct syntax in the writing. The purpose of the study is to build an effective mobile learning model. Through creating a mobile application, it can boost the teaching and learning process in Bahasa Melayu.

\section{OBJECTIVE}

The study presented in this paper has been designed to develop mobile AR for primary students to learn Bahasa Melayu. This study had three research objectives:

i. To identify suitable Instructional Design in developing mobile learning.

ii. To design and develop mobile augmented reality (AR) application for learning Bahasa Melayu based on the Instructional Design model.

iii. To evaluate AR mobile learning application in enhancing the understanding of Bahasa Melayu among students.

\section{SCOPE}

This project will focus on primarily on the children of age between seven (7) to twelve (12) years old. The project will be developed using Augmented Reality (AR) mobile application for Android platform. It will focus on two subtopics such as collective nouns and proverbs.

\section{METHODOLOGY}

\subsection{ADDIE Model Implementation in Project Development}

The development is based on the model of the ADDIE. The ADDIE is one of the development models used by most software developers. The ADDIE model was introduced as a methodology in the first stage of a small quantitative method [6]. Instructional design can be defined as the development of teaching materials, modules or lessons. The training design process includes the assessment of student needs, the identification of overall goals and objectives for teaching, the design and preparation of evaluation tasks and the development of education and learning activities to ensure the quality of teaching. The instructional designer must choose the model of instruction that best serves research and development. As shown in Figure 1, the design of the ADDIE model.

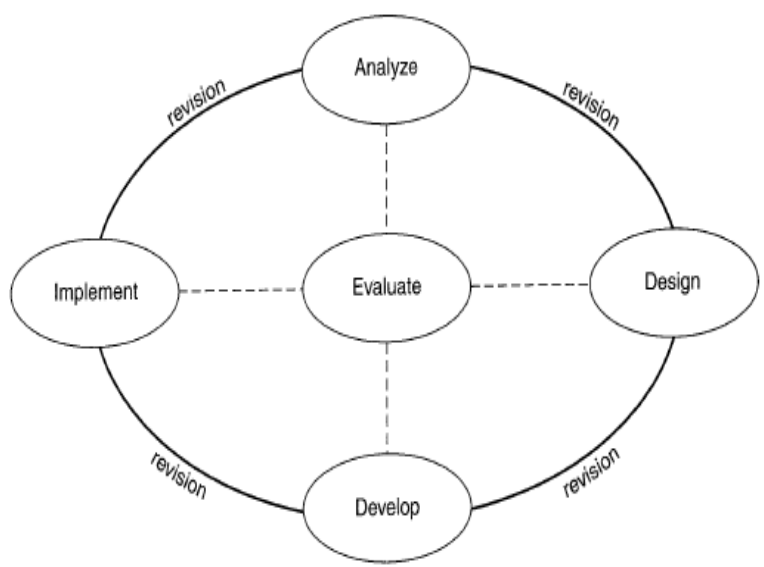

Figure 1: ADDIE Model

Based on Figure 1, there are five phases in the ADDIE model. The phases are analyzed, design, develop, implement and evaluate.

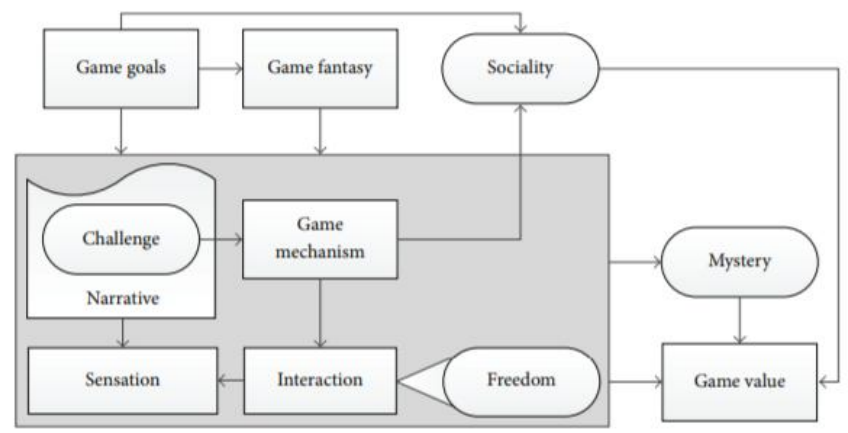

Figure 2: Game-Based Learning (GBL) Model

On the other hand, for designing and developing the AR mobile learning application, author decided to use GameBased Learning (GBL) model as shown in Figure 2. It consist of eight (8) elements as listed below:

i. Game story background: Plots are a key component of sports. There are some games that do not seem to have any plots, but you see that they have a lot to do with them when you look closer. You are responsible for the execution of the plot in your play. 
ii. Rules: Regulations and guidelines, case studies and copies of current practices are necessary to inform and improve the quality of game-based learning throughout the industry and to support better planning and allocation of resources for the future. The use of both leisure games and proprietary games must be effectively and integrated in practice, in line with sound pedagogical principles and design.

iii. Immersive: Game-based learning offers new ways to re-think how we learn. With immersive spaces, pupils can produce materials for themselves, share learning experience and rehearsal skills for the real world. Video games and computer applications to create enticing and engaging learning experiences for unique learning purposes.

iv. Enjoyment: Applying game-based learning will change student's skills, retain information and apply their training. With the emergence of new technology, the popularity of education games is only increasing; its use in the aviation, military and healthcare industries has already spill over where workers are entitled to play games in a healthy learning environment. Today's game-based training schools and districts can better prepare their students for the future.

v. Feedback: The students were asked to fill in feedback sheets and undergo interviews after the game. Experimental results showed that the inclusion of game elements in courses would improve the degree of student interest and would allow students to spend their time in classes because they want to benefit and thus achieve the goal of encouraging learning.

vi. Multimedia Technology: The students can learn through the combination of text, images, video, sound, and animation. [16] have conducted investigations that allow students to create flexible and original ideas through multimedia. Interactive multimedia creates an anxiety-free learning environment [24].

vii. Challenge \& Competition: New developments like the serious game movement promote collaboration among educational, industrial and government organizations to create own games for learning. There must be more research to bring together the game development and education communities to create common vocabulary and standards and to advise new learning concepts to better effectively construct game-based learning experiences.

viii. Reward/Award: Educators have considerable potential to participate in developing learning content related to these new games in this phase. It can further be promoted by using participatory methodological developing methodologies to ensure that trainers and learners have a more effective say in specialized content that has been developed for games-based education.

\section{EXPECTED RESULTS}

Overall, the expected results in this study is to assist an interactive way of teaching and learning process based on Instructional Design, which is ADDIE model. Besides that, the Instructional Design Model in enhancing the understanding of Bahasa Melayu among students in designing and developing mobile AR for learning Bahasa Melayu. Therefore, this project is to help Bahasa Melayu especially in both of these subtopics, such as collective names and proverbs, in primary school students aged 7 to 12 years.

\section{CONCLUSION}

ADDIE model is chosen because it is the famous model used by instructional designer in mobile learning design and development. New teaching opportunities with mobile games are emerging to technological developments [13]. However, most information about processes through which mobile game-based learning has beneficial impacts remains to be discovered [12]. Teachers and students can learn from teaching media and technology together because learning can be handled anywhere [33].

Today in education around the world, we can find some great examples of through reality. The ability to link reality and digital content is steadily improving and providing educators and students with more possibilities. The potential benefits of AR technology include the capacity of AR to foster psychological conditions in students that can affect learning outcomes in a positive manner. In AR, the location and timetable of the analysis are modified and new approaches can be added. Increased real-world technology skills will make classes more appealing and interactive. The key aspect of this project is that it contributes to an interactive and exciting approach to the knowledge process by means of methods that differ from previous AR [5]. Motivation is a source of energy for students who determine how long they are willing and how difficult it is to try, and how closely related they are to the task [23]. Multiple studies [4]; [7]; [11] have reported success in AR based research activities to encourage motivation for students.

\section{ACKNOWLEDGEMENT}

Authors would like to thank Universiti Teknikal Malaysia Melaka (UTeM), Center for Research and Innovation Management (CRIM), Center for Advanced Computing Technology (C-ACT), Pervasive Computing \& Educational Technology (PET) and others who assisted and took part in the research. Thank you to CRIM for sponsoring the publication fees of the short grants number PJP/2019/CRIM (3D) S01686.

\section{REFERENCES}

1. Abdul Jabbar, A. I. A., \& Felicia, P. Gameplay engagement and learning in game based learning. Review of Educational Research, 2015. 85, 740-779. http://doi.org/10.3102/0034654315577210. 
2. Azuma, R., Baillot, Y., Behringer, R., Feiner, S., Julier, S., \& MacIntyre, B. Recent advances in augmented reality. IEEE Computer Graphics and Applications, 2001. 21 (6), 34-47. https://doi.org/10.1109/38.963459

3. Billinghurst, M. Augmented reality in education. New Horizons for Learning. 2002. Retrieved from http://www.newhorizons.org/strategies/technology/bill inghurst.htm,

4. Cascales-Martínez, A., Martínez-Segura, M. J., PerezLopez, D., \& Contero, M. Using an augmented reality enhanced tabletop system to promote learning of mathematics: A case study with students with special educational needs. Eurasia Journal of Mathematics, Science and Technology Education, 2017. 13(2), 355-380.

5. Che $\mathrm{Ku}$ Nuraini Che $\mathrm{Ku}$ Mohd, Gede Pramudya Ananta, Faaizah Shahbodin, Helmi Adly Mohd Noor, Muliati Sedek. Using Interactive Games to Engage Children with Autism on Visual Impairment. International Journal of Recent Technology and Engineering, ISSN: 2277-3878, Volume-8 Issue-3, September 2019, 5995-5999.

6. Che $\mathrm{Ku}$ Nuraini Che $\mathrm{Ku}$ Mohd, Faaizah Shahbodin, Suriawati Suparjoh, Nur Alya Sahira Muhamad Khidir. Application of Augmented Reality in Learning Bakery for Autism Spectrum Disorder. International Journal of Engineering and Advanced Technology. ISSN: 2249 - 8958, Volume-9 Issue-1, October 2019, 2616-2620.

7. Chang, K.-E., Chang, C.-T., Hou, H.-T., Sung, Y.-T., Chao, H.-L., \& Lee, C.-M. Development and behavioral pattern analysis of a mobile guide system with augmented reality for painting appreciation instruction in an art museum. Computers \& Education, 2014. 71, 185-197.

8. Chiang, T. H. C., Yang, S. J. H., \& Hwang, G.-J. An Augmented Reality-based Mobile Learning System to Improve Students' Learning Achievements and Motivations in Natural Science Inquiry Activities. 2014. Educational Technology \& Society, 17(4), 352365.

9. Furió, D., Juan, M.-C., Seguí, I., \& Vivó, R. Mobile learning vs. traditional classroom lessons: A comparative study. Journal of Computer Assisted Learning, $\quad 2015 . \quad 31, \quad$ 189-201. http://doi.org/10.1111/jcal.12071.

10. Gecu-Parmaksiz, Z., \& Delialioglu, O. Augmented reality-based virtual manipulatives versus physical manipulatives for teaching geometric shapes to preschool children. 2019. British Journal of Educational Technology.

11. Georgiou, Y., \& Kyza, E. A. Relations between student motivation, immersion and learning outcomes in location-based augmented reality settings. 2018. Computers in Human Behavior, 89, 173-181.

12. Iten, N., \& Petko, D. Learning with serious games: Is fun playing the game a predictor of learning success? British Journal of Educational Technology, 2016. 47, 151-163. http://doi.org/10.1111/bjet.12226.
13. Jantina Huizenga,Wilfried Admiraal, Geert ten Dam, Joke Voogt. Mobile game-based learning in secondary education: Students' immersion, game activities, team performance and learning outcomes. Computers in Human Behavior. Computers in Human Behavior 99 (2019), pp. 137-143.

14. Johnson, L., Adams Becker, S., Cummins, M., Estrada, V., Freeman, A., \& Hall, C. NMC Horizon Report: 2016 Higher Education Edition. Austin, Texas: The New Media Consortium.

15. Kaufmann, H., \& Schmalstieg, D. Mathematics and Geometry education with collaborative augmented reality. In ACM SIGGRAPH 2002 conference abstracts and applications (pp. 37-41). ACM.

16. Kassim, H., Nicholas, H., \& Ng, W. (2014). Using a multimedia learning tool to improve creative performance. Thinking Skills and Creativity, 2014, 13, 9-19.

17. Kaur, N., Pathan, R., Khwaja, U., Sarkar, P., Rathod, B., \& Murthy, S. GeoSolvAR: Augmented reality based application for mental rotation. In 2018 IEEE tenth international conference on technology for education 2018, (T4E) (45-52). IEEE.

18. Kerawalla, L., Luckin, R., Seljeflot, S., \& Woolard, A. Making it real: Exploring the potential of augmented reality for teaching primary school science. Virtual Reality, 10(3-4), 2006, 163-174. London, United Kingdom: Springer-Verlag London Ltd.

19. Lee, I. J. Using augmented reality to train students to visualize three-dimensional drawings of mortisetenon joints in furniture carpentry. Interactive Learning Environments, 2019, 1-15.

20. Lee, K. Augmented reality in education and training. TechTrends: Linking Research and Practice to Improve Learning, 2012, 56(2), 13-21. http://dx.doi.org/10.1007/s11528-012-0559-3

21. Martín-Dorta, N., Saorín, J. L., \& Contero, M. Development of a fast remedial course to improve the spatial abilities of engineering students. Journal of Engineering Education, 2008, 97(4), 505-513.

22. Nail B, Ammar WA. Mobile Learning Education has Become More Accessible. Am J Compt Sci Inform Technol 5: 2. 2017, doi: 10.21767/2349-3917.100005

23. Rost, M. Generating student motivation. WorldView, 2006, 1-4.

24. Sanaky, Hujair AH. Media pembelajaran interaktifinovatif. Yogyakarta: Kaudaba Dipantara, 2013.

25. So, H. J., \& Seo, M. A systematic literature review of game-based learning and gamification research in Asia. Routledge International Handbook of Schools and Schooling in Asia Routledge. https://www.routledgehandbooks.com/doi/10.4324/978 1315694382-37,2018.

26. Sung, Y., Chang, K., \& Liu, T. The effects of integrating mobile devices with teaching and learning on students' learning performance: A meta-analysis and research synthesis. Computers \& Education, 94, 252-275.2016, http://doi.org/10.1016/j.compedu.2015.11.008.

27. Tobar-Muñoz, H., Baldiris, S., \& Fabregat, R. Augmented Reality Game-Based Learning: 
Enriching Students Experience during Reading Comprehension Activities. 2017, Journal of Educational Computing Research.

28. Wilson, K. A., Bedwell, W. L., Lazzara, E. H., Salas, E., Burke, C. S., Estock, J. L., et al. Relationships between game attributes and learning outcomes. Simulation \& Gaming, 40, 217-266. 2009, https://doi.org/10.1177/1046878108321866.

29. Wouters, P. J. M., Van Nimwegen, C., Van Oostendorp, H., \& Van der Spek, E. D. A metaanalysis of the cognitive and motivational effects of serious games. Journal of Educational Psychology, 105, 249-265, 2013, http://doi.org/10.1037/a0031311.

30. Yuen, S. C.-Y., Yaoyuneyong, G., \& Johnson, E. Augmented reality: An overview and five directions for $\mathbf{A R}$ in education. Journal of Educational Technology Development and Exchange, 2011, 4(1), 119-140. https://doi.org/10.18785/jetde.0401.10

31. Aaron Don M. Africa, Francis Miguel M. Espiritu, Christian Rodel V. Lontoc, Roger Jayson M. Mendez III. The Integration of Computer Systems into the expansive field of Video Games. International Journal of Advanced Trends in Computer Science and Engineering. Volume 8, No.4, July - August 2019.https://doi.org/10.30534/ijatcse/2019/22842019.

32. Muhammad 'Azizi Che Sulaiman, Ainita Ban. User Interface Guidelines for Dyslexic Game-Based Learning on Selected Usability Test Method. International Journal of Advanced Trends in Computer Science and Engineering. Volume 8, No. 1.4 , 2019.https://doi.org/10.30534/ijatcse/2019/6981.42019.

33. Marilou B. Carnicer. The Use of Educational Data Mining Technique in Technology Assimilation Evaluation: A Response Assessment. International Journal of Advanced Trends in Computer Science and Engineering. Volume 8, No.3, May - June 2019. https://doi.org/10.30534/ijatcse/2019/50832019. 